\title{
Geothermal Power Growth 1995-2013-A Comparison with Other Renewables
}

\section{Journal Article}

\section{Author(s):}

Rybach, Ladislaus

Publication date:

2014-08

Permanent link:

https://doi.org/10.3929/ethz-b-000089300

\section{Rights / license:}

Creative Commons Attribution-NonCommercial-ShareAlike 3.0 Unported

\section{Originally published in:}

Energies 7(8), https://doi.org/10.3390/en7084802 
Article

\title{
Geothermal Power Growth 1995-2013-A Comparison with Other Renewables
}

\section{Ladislaus Rybach}

Institute of Geophysics, ETH Zurich, Sonneggstrasse 5, CH-8092 Zurich, Switzerland;

E-Mail: rybach@ig.erdw.ethz.ch; Tel.: +41-44-633-2076; Fax: +41-44-633-1065

Received: 4 April 2014; in revised form: 15 July 2014 / Accepted: 16 July 2014 /

Published: 24 July 2014

\begin{abstract}
Based on global statistical data the current status of deep geothermal resource utilization for electricity generation is presented. Particular attention is paid to growth rates. The rates are compared with those of other renewable energies (biomass, hydro, solar photovoltaic (PV), wind). Whereas wind and solar PV exhibit annual growth rates of $25 \%-30 \%$ since 2004 , geothermal growth is only about $5 \%$ per year. Geothermal electricity production (in TW/h/yr) was higher until 2011 than from solar PV, but is now clearly falling behind. So far the global geothermal electricity generation is provided nearly entirely by hydrothermal resources, which exist only under specific geologic conditions. Further development (=increasing production capacity) based on this resource type alone will therefore hardly accelerate to two-digit ( $>10 \%$ per year) growth rates. Faster growth can only be achieved by using the ubiquitous petrothermal resources, provided that the key problem will be solved: establishing a universally applicable technology. This would enable to create, at any requested site, feasible and efficient deep heat exchangers for enhanced geothermal systems (EGS) power plants-irrespective of the local subsurface conditions. Goals and challenges of this technology are addressed.
\end{abstract}

Keywords: electric power; current annual growth rates; future prospects

\section{Introduction}

Renewable sources of electricity are generating increasing interest and having a corresponding impact on the energy scene. Geothermal energy sources have the advantage of providing base-load electricity, i.e., independent of daily, seasonal or climatic variations and thus can complement other, intermittently producing renewable sources like wind or solar. Whereas wind and solar energy sources 
are abundant on the surface, for geothermal sources one has to go deep, usually a few kilometers. In the following, geothermal electricity is addressed and the global electricity supply from various renewable sources will be presented and compared. The growth rate in renewable power generation is a decisive factor on the electricity market.

\section{Geothermal Power Generation}

There are two main types of deep geothermal resources from which electricity can be produced: hydrothermal and petrothermal. Hydrothermal resources have naturally occurring geothermal fluids at depth, often originating from surface infiltration of precipitation. The fluids can be used as heat carriers and taken out from the ground through boreholes. Such hydrothermal resources like deep aquifers exist only when specific geologic/hydrogeologic conditions prevail, which makes them rather rare. Petrothermal resources on the other hand are more or less ubiquitous and immense; they consist basically of the "heat in place" in deep rock formations. The heat must be therefore extracted, e.g., by establishing a fluid circulation through a special, man-made heat exchanger at depth (see below for details). So far $99.99 \%$ of all existing geothermal power plants use hydrothermal resources. Figure 1 shows schematically the two resource types.

Figure 1. The two types of geothermal resources capable to generate electric power. The hydrothermal type on a natural reservoir that can feed, besides binary power plants, also geothermal steam condensing turbines. For the petrothermal type the reservoir needs to be created (details see text). Modified from Figure 3 in Geothermal Electricity (GEOELEC) Resource Assessment Protocol [1].

\section{Deep Geothermal Resource Types}

Hydrothermal

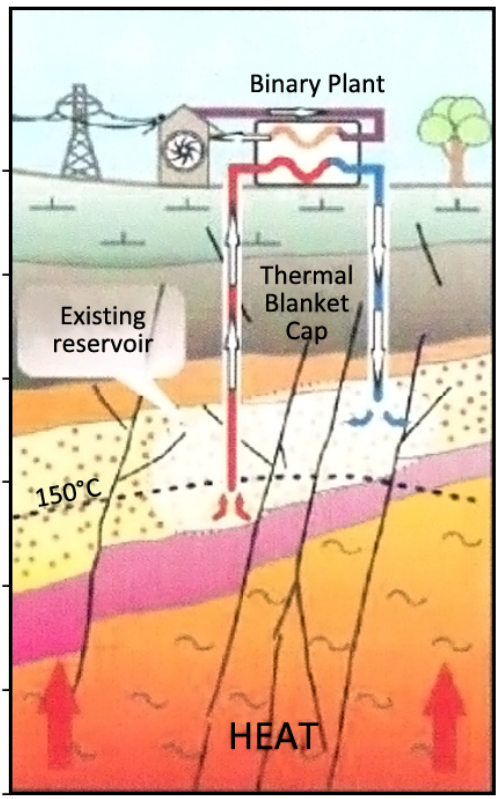

Heat carrier (steam/hot water) at depth is locally present

$\rightarrow$ rather rare
Petrothermal

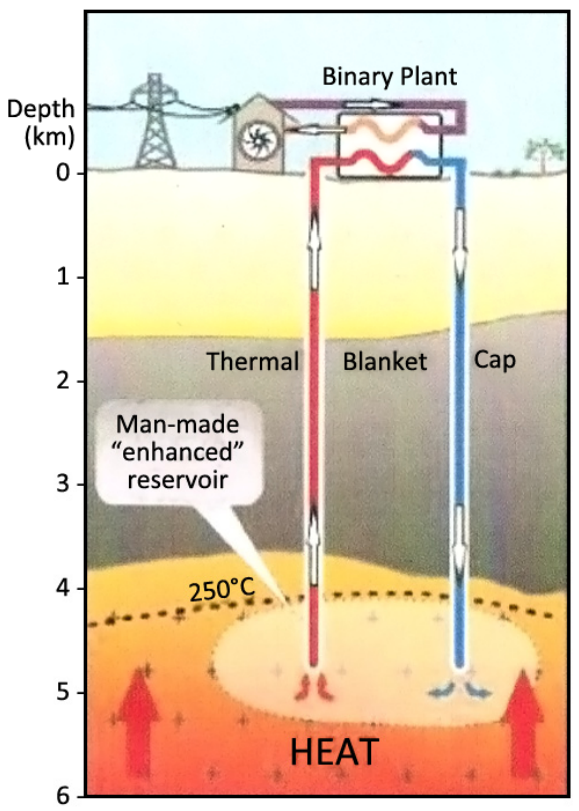

Heat carrier must be artificially circulated to extract heat $\rightarrow$ in principle ubiquitous 
Geothermal power plants provide base-load electricity. Currently, the total globally installed capacity amounts to about $12 \mathrm{GWe}$, in 24 countries, with a total production of $76 \mathrm{TW} \cdot \mathrm{h} / \mathrm{yr}$ [2]. So far, practically all power plants use hydrothermal resources. Geothermal power generation started in 1904 in Larderello, Italy. In earlier days, reservoirs with dry steam have been tapped, later also those with steam/water mixtures. Such high-temperature fields $\left(>200{ }^{\circ} \mathrm{C}\right.$ in less than $2 \mathrm{~km}$ depth) are mostly located in volcanic areas and are correspondingly rare. The average power plant size is about $50 \mathrm{MWe}$. The largest hydrothermal plant to date, at Toanga (previously called Nga Awa Purua) in New Zealand operates with a single 140 MWe turbine unit and is fed by only six production wells [3].

With advanced technology such as binary power plants it is now possible to convert heat to power also with lower fluid temperatures $\left(100-120^{\circ} \mathrm{C}\right)$. But the conversion efficiency is correspondingly low (a few percentage points only) and the plant size is also limited (only a few MWe).

Below a global comparison is presented between geothermal and the other renewable energies, in terms of both potential and power generation. Development growth is presented for wind, solar photovoltaic (PV) and geothermal power and compared for the time period 1995-2013. In addition, a comparison is made of the annual geothermal production in 2013 with the renewables hydropower, biomass, solar PV and wind.

\section{Large Geothermal Potential}

A highly respected source (World Energy Assessment (WEA) - a collaborative effort between United Nations Development Programme (UNDP), United Nations Development of Economic and Social Affairs (UN DESA) and the World Energy Council (WEC)) attests the largest potential value to geothermal energy among all forms of renewable energy sources. The comparison is given in Table 1.

Table 1. Potential of renewable energy sources, from World Energy Assessment (WEA) [4].

\begin{tabular}{cc}
\hline Energy source & Capacity (EJ/yr) \\
\hline Geothermal & 5000 \\
Solar & 1575 \\
Wind & 640 \\
Biomass & 276 \\
Hydro & 50 \\
\hline Total & 7541 \\
\hline
\end{tabular}

The values are given in capacity units, i.e., energy per unit time. It is obvious that geothermal energy has the largest capacity, although the accuracy of the reported number is limited. This potential is so far only marginally developed.

\section{Growth Comparison over the Time Period 1995-2013}

Geothermal power development data is available for the time period 1960-2013 according to Geothermal Energy Association (GEA) 2012 [5] and 2000-2013 from GEA 2014 [6]. The growth is practically linear, with only small increase rate changes lately, see Figure 2. 
Figure 2. Growth of installed geothermal power (MWe) worldwide over the years 2000-2014 (from Geothermal Energy Association (GEA) 2014 [6]). Global growth 2004-2012 4\%.

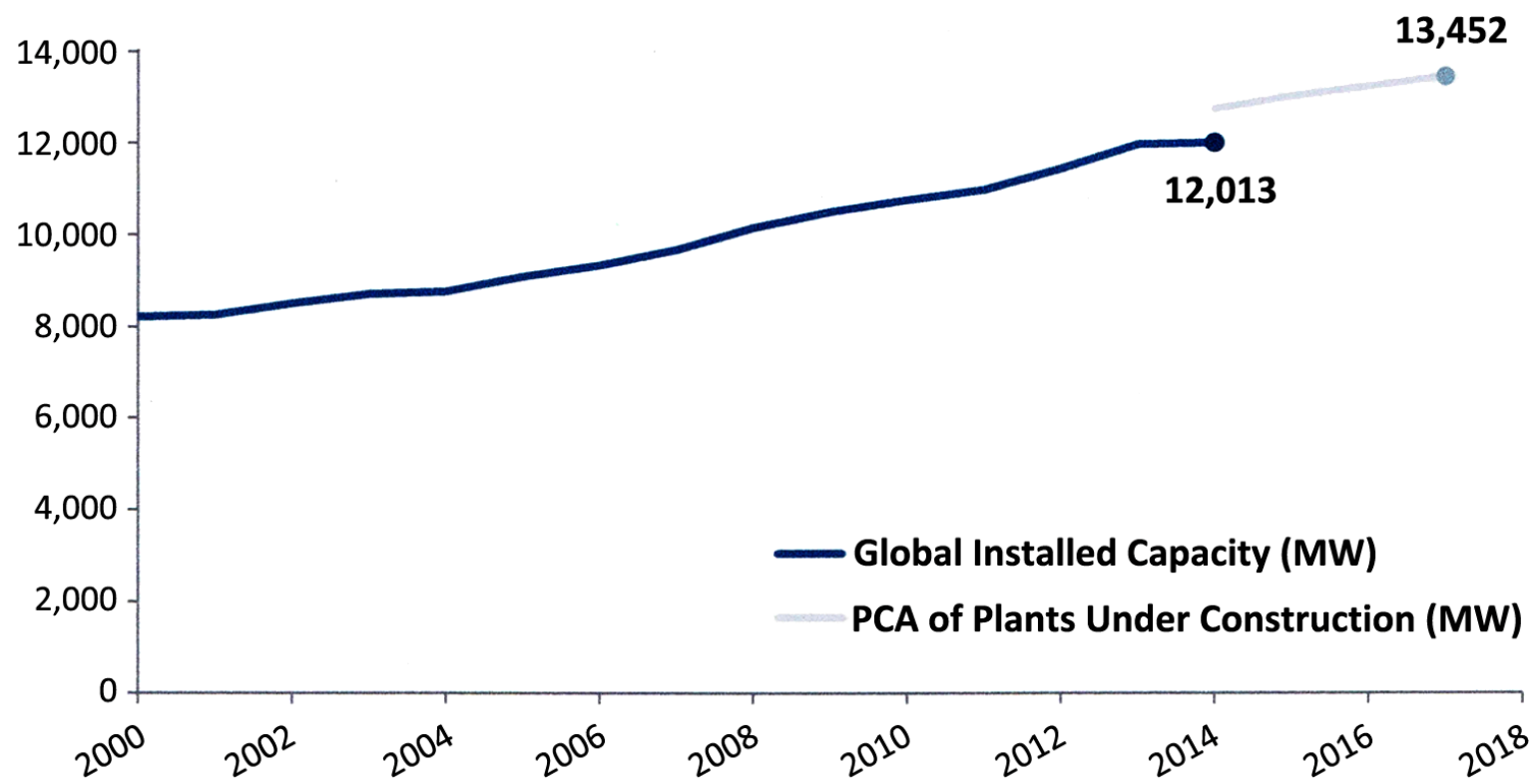

New data on the development of power generation from renewable sources is given in REN21 2014 [2]. The installed capacity of wind power shows a clearly accelerating trend of an exponential nature (Figure 3), with an annual growth rate of about $25 \%$.

Figure 3. Growth in global wind power development (GWe) over the years 2000-2013 from REN21 [2].

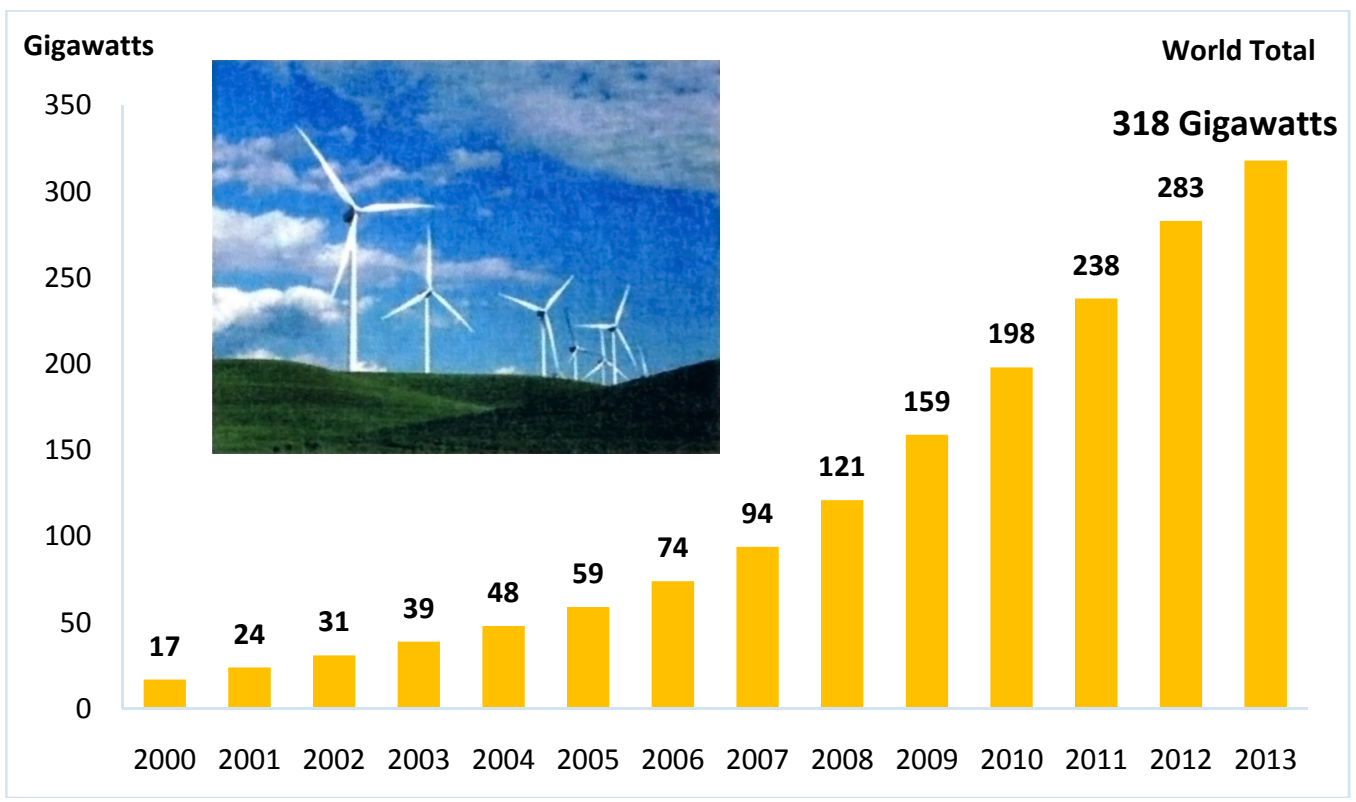

A similar trend of exponential growth is reported for solar PV power, both grid-connected and off-grid production already for 1995-2008. In Figure 4, the geothermal power growth in the same period - from [5] - is plotted for comparison. It is evident that geothermal had the lead over solar PV in the time before year 2007. Afterwards solar PV clearly took over. 
Figure 4. Global growth in solar photovoltaic (PV) development (MWe) 1995-2008 from REN21 2009 [7]. Geothermal power growth is plotted for comparison (data from [5]). Until about 2007 geothermal power was far ahead of solar PV.

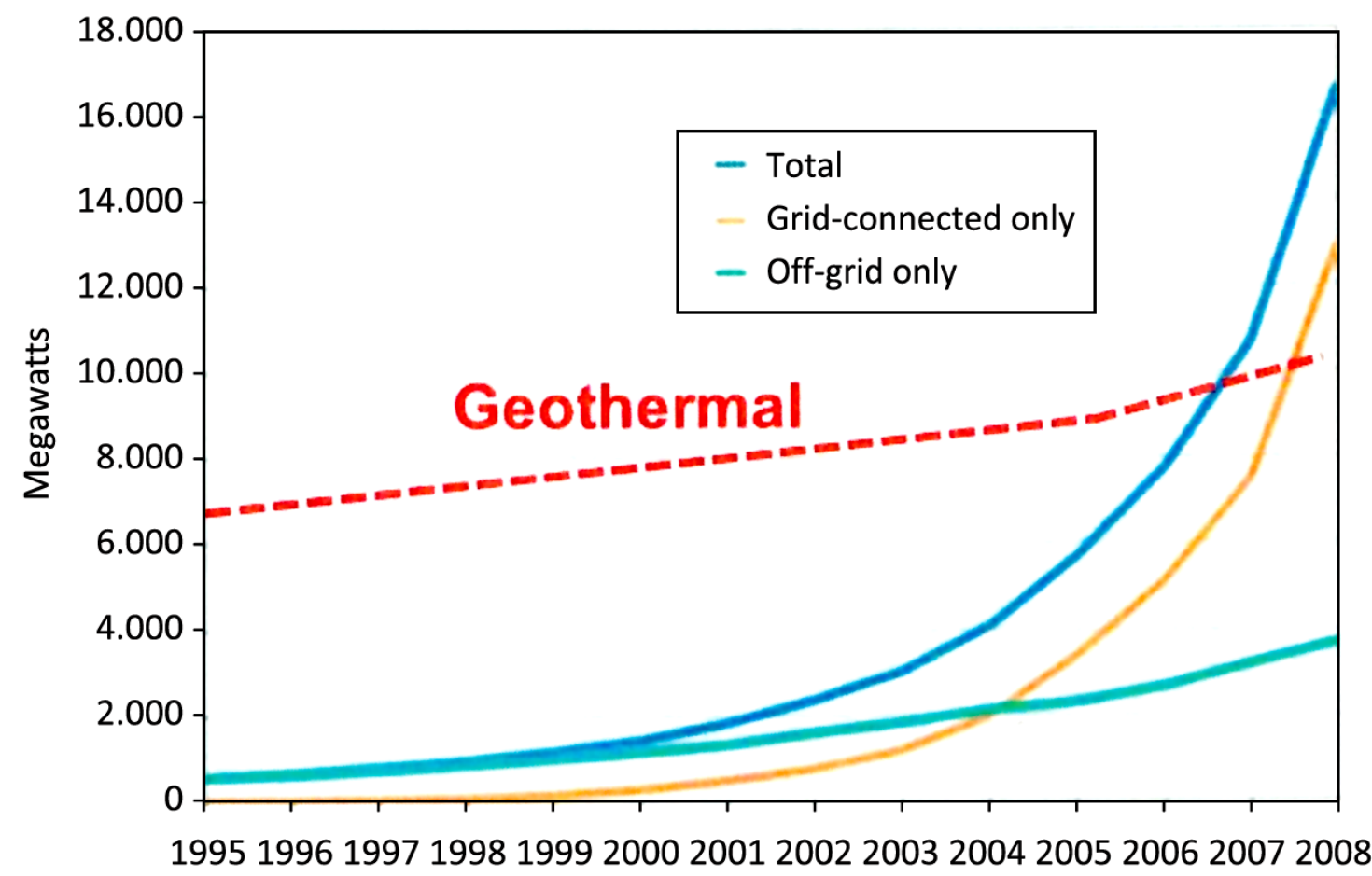

Now new solar PV data are available. Figure 5 shows the situation by end of 2013. For comparison, the geothermal data are plotted again. It is clear that geothermal is now left far behind. Here it must be noted that practically all geothermal power originates so far from hydrothermal resources.

Figure 5. Global growth in solar PV development (MWe) until 2013 from REN21 2014 [2]. Geothermal power growth (dashed line) is plotted for comparison-from Figure 2. Whereas solar growth is annually about $40 \%$, geothermal growth remains low at $4 \%$ per year.

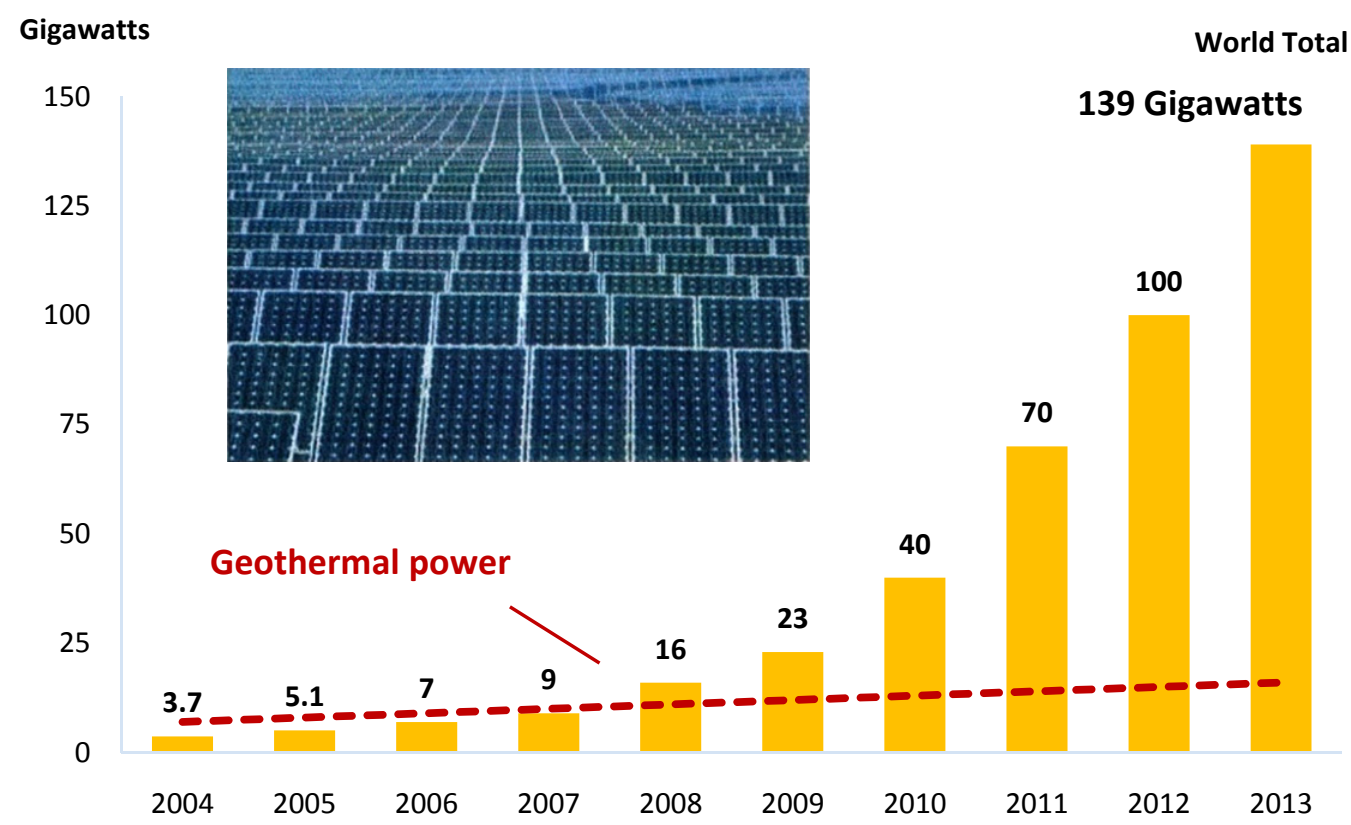


Here it must be emphasized that the Figures 2-5 refer to installed capacity, not to actual power production. What counts is the produced amount of electricity. Annual production data (in TW·h) are assembled in Table 2 for various renewable sources. Wind is not blowing at all times; the sun is shining only during daytime whereas geothermal production can go on at practically all times (except for production stops, for example during maintenance operations). This is reflected by the capacity factor (basically the percentage of yearly operating hours), given in Table 2. Sometime in 2011 solar PV took also over geothermal electricity in terms of global annual production; and the solar-geothermal gap is thus further increasing.

Table 2. Comparison of global electricity production by renewable technologies in 2013 (data from REN21 [2]).

\begin{tabular}{cccccccc}
\hline \multirow{2}{*}{ Technology } & \multicolumn{2}{c}{ Installed capacity } & & \multicolumn{2}{c}{ Annual production } & & Availability \\
\cline { 2 - 3 } & GWe & $\mathbf{\%}$ & & TW h/yr & $\mathbf{\%}$ & & \% \\
\hline Hydropower & 1000 & 64.2 & & 3680 & 74.9 & & 42 \\
Biomass & 88 & 5.7 & & 405 & 8.2 & & 53 \\
Wind & 318 & 20.4 & & 585 & 11.9 & & 21 \\
Geothermal & 12 & 0.8 & & 76 & 1.5 & & 72 \\
Solar PV & 139 & 8.9 & & 170 & 3.5 & \\
\hline Total & 1557 & 100 & & 4916 & 100 & \\
\hline
\end{tabular}

From the above comparison it is evident that currently geothermal power development is left behind wind and solar PV. Whereas geothermal development growth is more or less linear (steady but slow growth-just a few percent increase per year), wind and solar PV exhibit accelerating growth with a clearly exponential tendency. To keep pace geothermal growth needs to be speeded up too; in the following some possible ways and means to accomplish this are addressed, primarily for power generation.

\section{How to Achieve Accelerated Geothermal Power Growth?}

Until today the growth in installed geothermal power capacity originated entirely from "conventional", hydrothermal resources. Such resources are found in numerous but special places, with high-temperature geothermal fluids present in the subsurface at relatively shallow depths $(2-4 \mathrm{~km})$. Such "anomalous" places can mainly be found in volcanic terranes or in other regions, depending on their plate tectonic settings (details see e.g., in [8]). It can be expected that geothermal power development based on conventional high-enthalpy resources will remain more or less linear in the future; therefore some new technology is needed to provide the exponential growth component. In the following the case is made that enhanced geothermal systems (EGS) technology could play this role.

In a study commissioned by the Intergovernmental Panel on Climate Change (IPCC) a team of authors [8] estimated the growth curve in geothermal power development from the present to year 2050. Figure 6 shows the result (installed capacity as well as power production). The curves in Figure 6 also exhibit exponential character. 
Figure 6. Installed geothermal capacity and electricity production since 1995 and forecasts for 2010-2050. From [8].

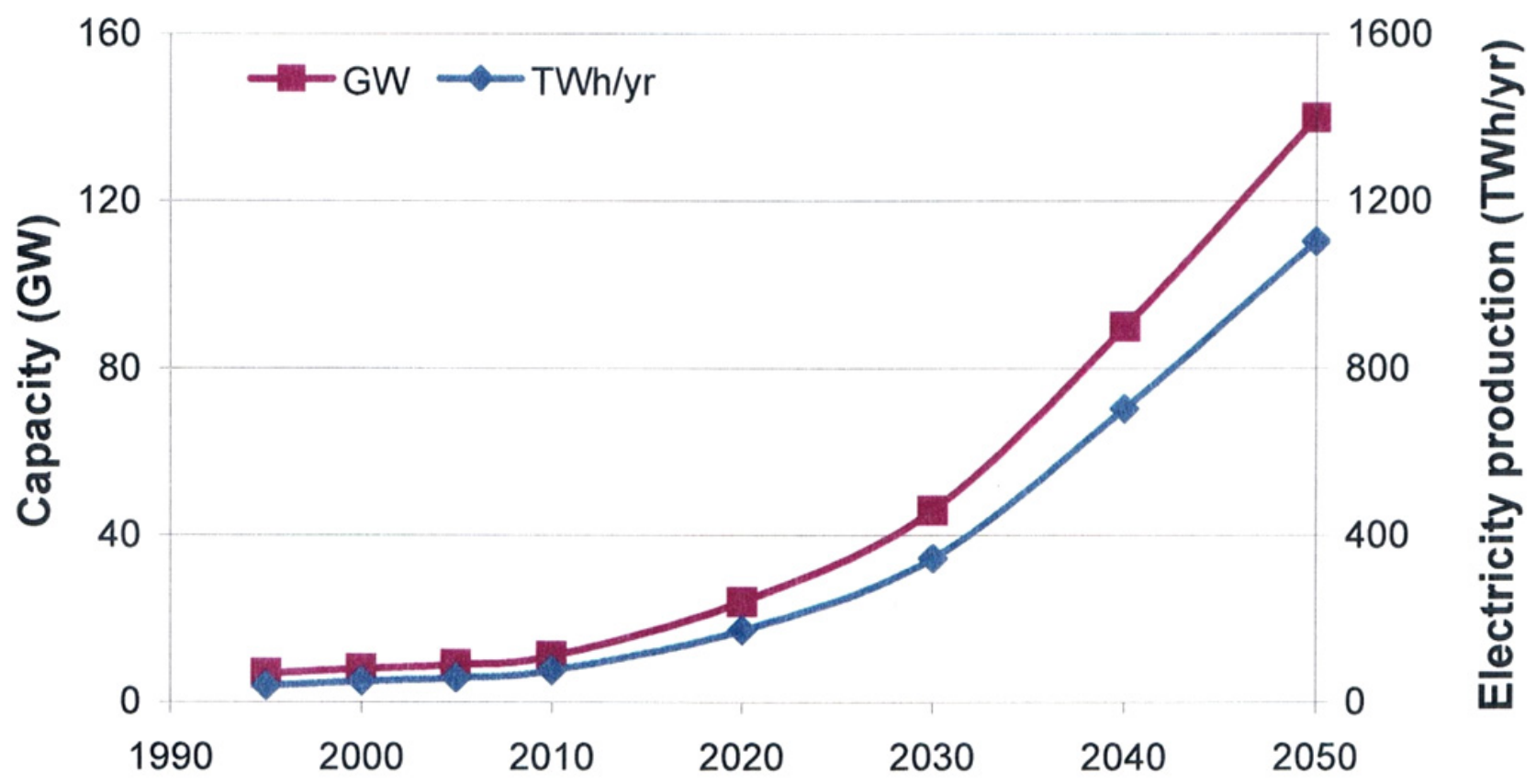

\section{EGS Technology: Goals and Open Questions}

The renowned Massachusetts Institute of Technology (MIT) [9] study "The Future of Geothermal Energy-Impact of EGS on the United States in the 21th Century" suggests that EGS will be the future of geothermal energy utilization. EGS is an umbrella term for various other denotations such as Hot Dry Rock, Hot Wet Rock, and Hot Fractured Rock. The MIT study determined EGS resources $>200,000$ EJ alone for the USA, corresponding to 2000 times the annual primary energy demand.

The EGS principle is simple: in the deep subsurface where temperatures are high enough for power generation $\left(150-200{ }^{\circ} \mathrm{C}\right)$ an extended, well distributed fracture network is created and/or enlarged to act as new fluid pathways and at the same time as a heat exchanger ("reservoir"). Water from the surface is pumped through this deep reservoir using injection wells and recovered by production wells as steam/hot water. The extracted heat can be used for district heating and/or for power generation.

The core piece of an EGS installation is the heat exchanger at depth. It is generally accepted that it must have a number of properties in order to be technically feasible and economically viable. These refer to the total volume, the total heat exchange surface, the flow impedance, and the thermal and stress-field properties. The key properties are summarized in Table 3.

Table 3. Required properties for an enhanced geothermal systems (EGS) reservoir (after RHC Platform [10]).

\begin{tabular}{cc}
\hline Fluid production rate & $50-100 \mathrm{~kg} / \mathrm{s}$ \\
\hline Fluid temperature at wellhead & $150-200{ }^{\circ} \mathrm{C}$ \\
\hline Total effective heat exchange surface & $>2 \times 106 \mathrm{~m}^{2}$ \\
\hline Rock volume & $>2 \times 108 \mathrm{~m}^{3}$ \\
\hline Flow impedance & $<0.1 \mathrm{MPa} /(\mathrm{kg} / \mathrm{s})$ \\
\hline Water loss & $<10 \%$ \\
\hline
\end{tabular}


Although the minimum requirements for an economically viable EGS reservoir are herewith set, their realization in a custom-made manner to comply with differing site conditions is not yet demonstrated. The key issue is the development of a technology to produce electricity and/or heat from a basically ubiquitous resource, in a manner relatively independent of local subsurface conditions, i.e., to develop a technology for the creation of EGS downhole heat exchangers-wherever needed-with the properties quantified above. Therefore, several questions about establishing and operating EGS heat exchangers that are still open need to be addressed and answered. Here are some of the key issues:

- Development of a technology to produce electricity and/or heat from a basically ubiquitous resource, in a manner more or less independent of site conditions.

- Site exploration must clarify the local temperature and stress field, lithology, kind and degree of already existing fracturation, natural seismicity.

- In creating EGS heat exchangers at several kilometers depth, questions of rock mechanics like the role of anisotropy degree, stress change propagation/transmission-fast/“dry"? slow/“wet"? (under different site conditions) — need to be answered.

- EGS induced seismicity (during stimulation in establishing the EGS heat exchanger but also during production) becomes a real issue, and thus needs to be controlled. Magnitudes need to be limited since public acceptance will be decisive [11].

- Uniform connectivity throughout a planned reservoir cannot yet be engineered. There is no experience with possible changes of an EGS heat exchanger over time; permeability enhancement (e.g., new fractures generated by cooling cracks) could increase the recovery factor while permeability reduction (e.g., by mineral reactions) or short-circuiting could reduce recovery.

- This leads to the question of production sustainability. The production level needs to be set in order to guarantee longevity of the system (details in [12]).

\section{Increasing EGS Power Plant Size}

In order to play a significant role on the electricity scene, geothermal power plants should have the size of at least some tens of MWe. So far, EGS plants (Soultz sous Forêts in France, Landau and Insheim in Germany) have just a few MWe installed capacity. Wind generators nowadays come with at least 2 MWe and can be installed, especially offshore, in large numbers.

One of the main future R\&D goals will be to work out how and to what extent could the EGS power plant size be upscaled. So far, there are only some theoretical calculations available; see e.g., [13]. In this publication an EGS scheme with 24 injection and 19 production wells is modelled, providing a net power output of around $60 \mathrm{MWe}$. Of course such ideas need to become substantiated by field evidence.

\section{European Geothermal Growth Perspectives, Financial Aspects}

The European Union has ambitious goals in term of renewable energy growth; the "20-20-20 goal" (20\% share of renewable energies, $20 \%$ energy savings and $20 \% \mathrm{CO}_{2}$ emission reduction until 2020) clearly calls also for more geothermal electricity. In the Union, a goal of 3 GWe EGS capacity has been proposed for the year 2020 and further substantial EGS growth by European Geothermal Energy Council (EGEC) [14], see Figure 7. 
Figure 7. Vision of European Geothermal Energy Council (EGEC) about geothermal electricity growth until 2050, from EGEC 2012 [14]. The largest share should come from EGS.

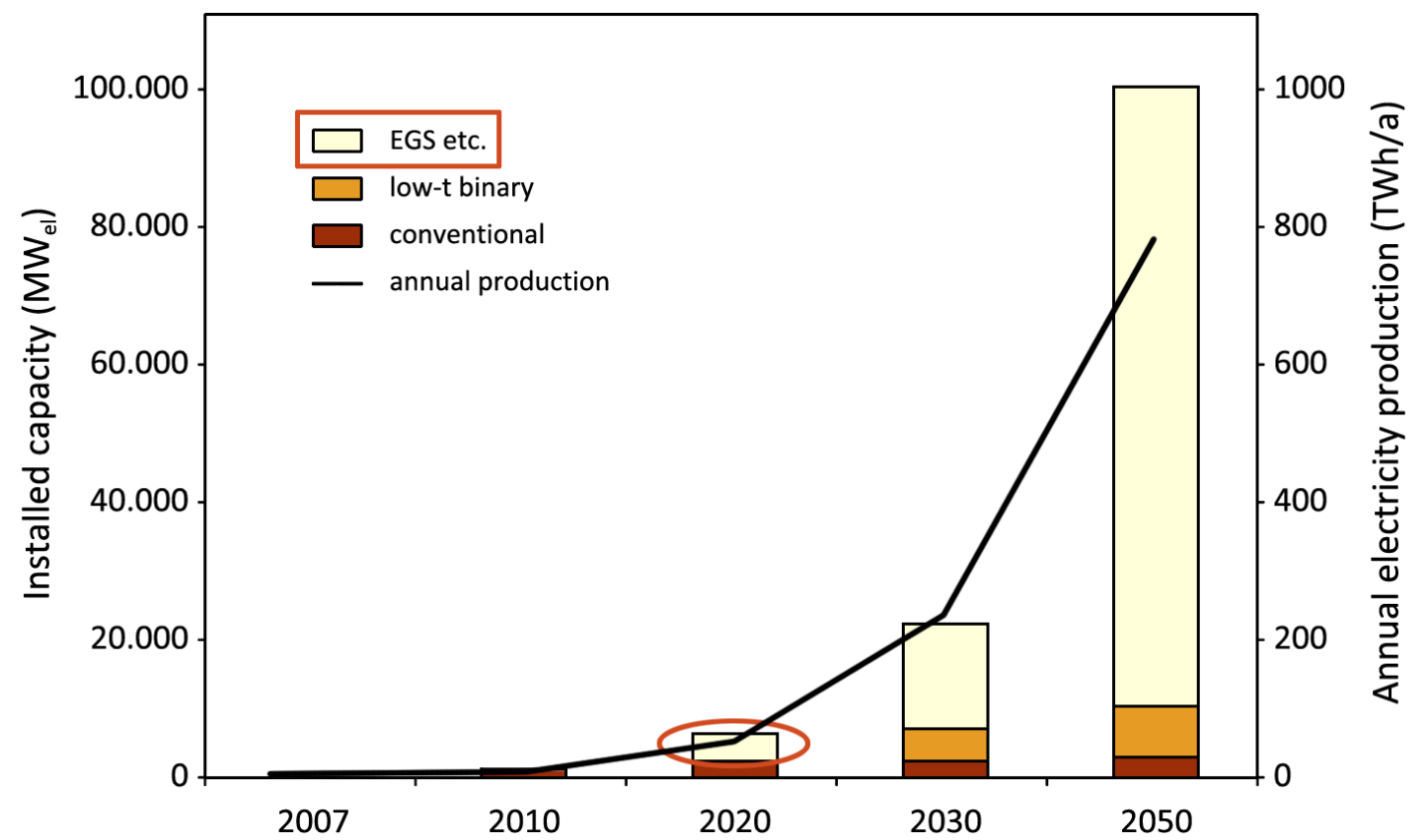

What financial sources would be needed for the realization of this vision? Currently the cost of establishing a generating capacity of 1 MWe from EGS (including exploration, drilling, stimulation, power plant, etc.) is estimated to be around 16 million $€$ according to Geothermal Electricity (GEOELEC) [15]. Thus the 3 GWe EGS capacity foreseen for 2020 in Europe (circled in Figure 7) would require an investment of about 50 billion $€$. Today it is unclear where such a funding would come from.

It is obvious from the above-described knowledge gaps that very substantial R\&D efforts are still needed to make EGS become the future of geothermal energy. Whereas some of the problems could be tackled by broad-based international cooperation, national R\&D programs have to provide additional means for the challenge. Public funding, mainly by governmental agencies, will be indispensable.

Although envisaged for conventional geothermal resources, Ibrahim [16] describes five steps to expedite development; four of them are based on fund allocations from national or regional governments. In any case it will be crucial to make rapid progress in tackling and solving the above-mentioned, still open financing problems.

\section{Conclusions and Outlook}

Geothermal power develops steadily world-wide, albeit with modest growth rates (a few \% per year). In some countries, like in Iceland, New Zealand or Turkey, the growth is remarkable. At the same time, wind and solar PV develop exponentially, with $30 \%-40 \%$ annual growth. In other words: globally, geothermal power falls increasingly back behind electricity from wind and solar PV.

Therefore, geothermal power growth should be accelerated. Since the development of hydrothermal resources cannot be accelerated much, mainly because such resources are limited; the only option that remains are petrothermal resources. The only problem: how to get out the heat in place? In particular, the following questions need to be addressed: 
- Where? (favorable site conditions $\rightarrow$ exploration)

- How? (sufficient, deep heat exchanger realization $\rightarrow$ proper, site dependent stimulation-without significant induced seismicity)

- With what efficiency? (recovery factor $\rightarrow$ enhancement of heat extraction, production sustainability). Recovery factor, $R(\%)=$ extractable heat/heat in place

Besides, upscaling EGS power plant size will be decisive. EGS pilot plants are badly needed, as is long-term experience. In addition, the financing of all the R\&D needs should also get solved. All these open questions need to be answered - and rather quickly so.

The future of geothermal power will strongly depend on to what extent can be the power plant deployment accelerated. Other sources of renewable energy are developing rapidly, especially wind and solar PV: wind energy recently accomplished to install 35 GWe additional capacity per year; solar PV reached $39 \mathrm{GWe} / \mathrm{yr}$, whereas geothermal power growth remains below $2 \mathrm{GWe} / \mathrm{yr}$. Even when one takes into account the higher geothermal capacity factor the need for speeding-up geothermal development is obvious. Accelerating EGS development could provide a break-through, under the condition that the necessary significant funding needs can be met. This, in turn, will require heavy engagement of both the public and the private sector.

\section{Conflicts of Interest}

The author declares no conflict of interest.

\section{References}

1. Van Wees, J.D.; Calcagno, P.; Dezayes, C.; Lacasse, C. A Methodology for Resource Assessment and Applications to Core Countries; Geothermal Electricity (GEOELEC): Brussels, Belgium, 2013. Available online: http://www.geoelec.eu/concep/library/ (accessed on 22 July 2014).

2. Renewables 2014: Global Status Report 2014; Renewable Energy Policy Network for the 21st Century (REN21): Paris, France, 2014.

3. Tadao, H.; Muto, T. Technical Features of Nga Awa Purua Geothermal Power Station New Zealand. In Proceedings of Renewable Energy 2010, Yokohama, Japan, 27 June-2 July 2010; Abstract O-Ge-4-4. Available online: http://www.re2010.org/ (accessed on 22 July 2014).

4. World Energy Assessment (WEA) Report: Energy and the Challenge of Sustainability; United Nations Development Programme (UNDP), Bureau for Development Policy, One United Nations Plaza: New York, NY, USA, 2000.

5. Geothermal: International Market Overview Report; Geothermal Energy Association (GEA): Washington, DC, USA, 2012.

6. Annual U.S. \& Global Geothermal Power Production Report; Geothermal Energy Association (GEA): Washington, DC, USA, 2014.

7. Renewables 2009: Global Status Report 2009; Renewable Energy Policy Network for the 21st Century (REN21): Paris, France, 2009. 
8. Fridleifsson, I.B.; Bertani, R.; Huenges, E.; Lund, J.W.; Ragnarsson, A.; Rybach, L. The Possible Role and Contribution of Geothermal Energy to the Mitigation of Climate Change. In Proceedings of the IPCC Scoping Meeting on Renewable Energy Sources, Luebeck, Germany, 20-25 January 2008; Volume 20, pp. 59-80.

9. Tester, J.W.; Anderson, B.J.; Batchelor, A.S.; Blackwell, D.D.; DiPippo, R.; Drake, E.M.; Garnish, J.; Livesay, B.; Moore, M.C.; Nichols, K.; et al. The Future of Geothermal Energy-Impact of Enhanced Geothermal Systems (EGS) on the United States in the 21st Century; Massachusetts Institute of Technology (MIT): Cambridge, MA, USA, 2006; p. 358. Available online: http://www1.eere. energy.gov/library/default.aspx?page $=4$ (accessed on 22 July 2014)

10. Strategic Research Priorities for Geothermal Technology; European Technology Platform on Renewable Heating and Cooling (RHC): Brussels, Belgium, 2012; p. 65. Available online: http://www.rhc-platform.org/publications/ (accessed on 22 July 2014).

11. Majer, E.; Baria, R.; Stark, M. Protocol for Induced Seismicity Associated with Enhanced Geothermal Systems; Report Produced in Task D Annex I; International Energy Agency-Geothermal Implementing Agreement: Taupo, New Zealand, 2008.

12. Rybach, L.; Mongillo, M. Geothermal sustainability-A review with identified research needs. GRC Trans. 2006, 30, 1083-1090.

13. Vörös, R.; Weidler, R.; de Graaf, L.; Wyborn, D. Thermal Modelling of Long Term Circulation of Multi-Well Development at the Cooper Basin Hot Fractured Rock (HFR) Project and Current Proposed Scale-Up Program. In Proceedings of the Thirty-Second Workshop on Geothermal Reservoir Engineering, Stanford, CA, USA, 22-24 January 2007.

14. European Geothermal Energy Council (EGEC). EGEC Vision for 2050 on Geothermal Power in Europe (Vision of ETP GEOELEC), 2012. Available online: http://egec.info/policy/tp-geoelec/ (accessed on 22 July 2014).

15. Geothermal Investment Guide; Geothermal Electricity (GEOELEC): Brussels, Belgium, 2011; p. 32. Available online: http://www.geoelec.eu/concep/library/ (accessed on 22 July 2014).

16. Ibrahim, H.D. Why is Geothermal Development Slow-How to Accelerate It? Petrominer Monthly Magazine, 1 July 2009; Volume 7, pp. 28-29.

(C) 2014 by the authors; licensee MDPI, Basel, Switzerland. This article is an open access article distributed under the terms and conditions of the Creative Commons Attribution license (http://creativecommons.org/licenses/by/3.0/). 